\title{
Social imaginaries of subsea cables: Recovering connections between Broome and Banyuwangi
}

\begin{tabular}{|c|l|}
\hline Journal: & Media International Australia \\
\hline Manuscript ID & MIA-20-0144.R1 \\
\hline Manuscript Type: & Original Article \\
\hline Keywords: & $\begin{array}{l}\text { cable, telegraph, Indian Ocean, Broome, Banyuwangi, social imaginaries, } \\
\text { Java, Western Australia, memory, Indigenous }\end{array}$ \\
\hline Abstract: & $\begin{array}{l}\text { As most data travels through subsea cables, this article investigates } \\
\text { social imaginaries of the cable laid in 1889 from Banyuwangi in south- } \\
\text { eastern Java to Broome in north-western Australia. Through } \\
\text { collaborative fieldwork in Broome and Banyuwangi, radically different } \\
\text { representations are identified at either end of the cable. In Broome, the } \\
\text { cable telegraph station is memorialized for introducing colonial } \\
\text { sophistication to a town where Java is celebrated for facilitating } \\
\text { communication with Britain. In Banyuwangi, there is no mention of } \\
\text { Broome and little mention of the undersea cable. Instead, there are } \\
\text { mythical and haunted representations of a decrepit British Hostel } \\
\text { occasionally associated with telegraph operations. Despite some } \\
\text { similarities in Indigenous perspectives and entrepreneurial desire to } \\
\text { realize tourism income from cable heritage, an ocean-size gulf was } \\
\text { identified between the social imaginaries that enabled the cable to be } \\
\text { dug up and normalized as a cultural attraction in Broome while } \\
\text { remaining buried, almost forgotten, in Banyuwangi. }\end{array}$ \\
\hline
\end{tabular}

\section{SCHOLARONE Manuscripts}




\section{Social imaginaries of subsea cables: Recovering connections between Broome and}

\section{Banyuwangi}

When a 4,600km subsea cable from Perth to Singapore via Indonesia was completed in 2018, Australia's Communication Minister declared, ‘Although many people probably don't know it, almost all of the internet traffic from Australia to the world goes by subsea cables' (Vocus Communications, 2018). As substantial investments are being made in subsea cables, this article addresses the question of how public knowledge has sedimented around some of the earliest landing sites for undersea cables connecting 'Australia to the world'. It describes an investigation into representations of the 1,650-kilometre-long submarine cable laid in 1889 from Banyuwangi in the colonized lands of the Blambangan people at the eastern tip of Java, to Broome in Yawuru country on the north-western coast of Australia. Fieldwork and archival research for this article was conducted by both researchers in Broome in November and Banyuwangi in December 2019, followed by textual analysis and desk research in the first half of 2020. The investigations' locally informed analysis of available texts indicates radically different social imaginaries of subsea cable heritage in Broome and Banyuwangi. The cable has been memorialized and put on display in Broome but remains buried and, largely, forgotten in Banyuwangi. The old telegraph technology is remembered, publicly, in Broome as a marvel of the world-wide-communications infrastructure of British Empire. Remnants of the subsea cable operations have been normalized as national heritage, functioning state infrastructure and as tourist attractions celebrating British sophistication in Broome, yet in Banyuwangi the only publicly available representations of cable heritage were associated with a haunted, semi-inhabited complex of buildings that the local government intends to reclaim from the army for a commercial heritage development targeting international tourists. The variance in representations of cable heritage suggest substantial differences in social imaginaries dominating the two sites. However, similarities could also be 
identified in how Indigenous heritage leaders at both sites supported the collection of archives to understand how subsea cable operations had impacted on their peoples within contexts of substantially older Indian Ocean rim communications. Finally, the article reflects on how onsite collaborative research brings out and may intervene in the social imaginaries of communities at either end of subsea cables.

\section{Eastern telegraph cables: disrupting and producing communities}

In the second half of the $19^{\text {th }}$ century, the resources, security and spatial organization of Indigenous peoples were radically disrupted by installation of the British telegraph system within today's geographies of Indonesia and Australia (Owen, 2016: 298-299; Martinez, 2017: 230-231). Submarine telegraph cables were laid from Darwin to Banyuwangi in 1871 and from Banyuwangi to Broome in 1889 to link the relatively new telegraph networks in Australia and Southeast Asia. The cables and cable stations were constructed and operated as part of the world-wide cable cartel led by a British merchant, John Pender (Headrick \& Griset, 2001; Thomas, 2019). In 1869, Pender founded companies to build cable networks from Madras (Chennai) in India to Singapore, from Singapore to Hong Kong and from Singapore to Darwin (Headrick \& Griset, 2001: 561). In 1873 these companies were merged into the Eastern Extension Australasia and China Telegraph Company, which became part of Eastern and Associated Telegraph Companies which then connected England to Brazil, America's west coast, Africa and the Caribbean. In quick succession all the continents were connected in a single network, supervised from a building in London, through which 'passed over half the world's international news dispatches, commercial messages and diplomatic telegrams' (Headrick \& Griset, 2001: 561-562). A telegraphic system around the world was established in British control, dominating East and Southeast Asia until the 1930s when it was challenged by the procurement and development of telecommunications networks by Japanese military, government and commercial enterprises (Yang, 2010: 20). In 1904, the 
Dutch government mistakenly thought it had liberated communications with its East Indies Colonial territory from the British telegraph system by operating a German-Dutch undersea cable from Sulawesi to Shanghai and Guam. The connecting cables from Shanghai to Europe and from Guam to America were owned by Danish and American companies but these, in turn, were owned secretly by Pender's cartel (Headrick \& Griset, 2001: 567). In 1937, a leading Japanese telecommunications engineer reported that the Dutch East Indies had become the centre of telecommunications in the East, producing equipment locally in case supplies from Europe were cut (Yang, 2010: 197). From a British colonial perspective too, Java was the 'intermediary link, passing messages between Australia and London' (Martinez, 2017: 230). The telegraph network supported an 'Indian Ocean colonial culture' (2017: 227) and 'the right to rule' (Rizvi, 2017: 316) - that endured after Australia's federation in 1901. This culture's demand for subordinate Asian staff in the northern regions was in friction with white Australian nationalist calls for restriction of Asian migration. By World War 1, the direct undersea cable link between Java and Australia had become commercially redundant because of the installation of newer cables across the Indian Ocean to Australia. Then, in World War 2, all undersea cable connections to Australia from Southeast Asia were severed as Japanese Forces occupied the region (Yang, 2010). Despite this break and the slow collapse of British empire, the cultural, commercial and political legacies of its infrastructure in former Indian Ocean colonies can still be identified (Kerr, 2012; Martinez, 2017; Thomas, 2019).

\section{Approaching the cable stations}

To identify legacies of the undersea cable operations, the authors conducted fieldwork together in Broome in November and Banyuwangi in December 2019. Fieldwork was approached with an ethnographic sensibility towards people making meanings - inscribed in their representations of infrastructure in expected and unexpected forms (Von Schnitzler, 
2013) - based on their circumstances (Star, 1999) away from the urban sociality (Rizvi, 2017) of provincial capital cities. Informed by Kusno's (2000) investigations of colonial and postcolonial entanglements in representations of built environments, this approach was sensitive to indications of 'remembrance and amnesia' (2000: 16) in the two towns. In Broome, we met nine informants working in heritage, media, archival and arts services; and had internet or telephone conversations with two other informants who have contributed substantially to Indigenous and colonial heritage in Broome. Prior Internet research and the meetings with informants focussed our fieldwork on Cable Beach, Broome Historical Society \& Museum and Broome Courthouse. Photographs of texts at these sites were subject to textual analysis by close reading along with sections of relevant books suggested by staff in Broome's public library and local bookstores, and video documentaries given to us by the television station in Broome, Goolarri Media Enterprises. In Banyuwangi, we arranged a meeting to discuss cable heritage with the Regent, Abdullah Azwar Anas. The Banyuwangi Regent was accompanied by local government staff and journalists that he invited to follow the meeting and interview us afterwards. The Regent also provided his recently released book, Anti-Mainstream Marketing: 20 Ways Changing Banyuwangi (Anas, 2019). In this book on the development of Banyuwangi city during his leadership, Anas describes current plans to revitalise heritage buildings in the city including an old colonial building complex, known locally as Asrama Inggrisan (British Hostel). Later, we were joined in a tour of the complex by local archaeologist Bayu Ari Wibowo, who subsequently confirmed that the 19th century complex had contained housing for telegraph station employees (personal communication, 2019). We visited the empty, decaying office that had been used to transmit telegrams to and from Australia, via Broome. Other buildings had become home to Indonesian soldiers and their families in the vast complex that looks out across Banyuwangi's town square towards Boom Beach and the harbour from which the cables were laid under the sea to Broome. During our fieldtrip to Banyuwangi, we found no official plaques, brochures or posters in 
public places referring to the telegraph station or undersea cable. Instead, we found overt and implied references to British colonists in the online films, social media posts and personal communications of professionals and volunteers who have produced, collected or shared recordings of Banyuwangi heritage. We examined Facebook Groups where members' views and experiences on the heritage 'related to their specific subjectivity' (Allmark and Wahyudi, 2019: 638). We also interviewed Munawir, founder and caretaker of Banyuwangi Tempo Doeloe (Olden Days Banyuwangi) community, to seek more insights on how community remembered the cable connection. Analysing these texts as normative utterances through the lens of social imaginaries provides insights on the background structures (Steele, 2017) through which the texts emerged. We utilise Cornelius Castoriadis' notion on social imaginary as '.. the creation of each historical period, its singular manner of living, of seeing and of conducting its own existence' (1987: 145). We approached each text as 'an engagement with the languages and practices of the social imaginary' (Steele, 2017: 1063) of the person or organization uttering the text. Our findings are presented below by location then in connection to one another.

\section{Maintaining Broome Cable Station and Cable Beach in Yawuru Country}

Arriving in Broome airport on 9 November 2019, the Shuttle Service sign offers visitors two directions, to 'TOWN' or 'CABLE BEACH'. Adjacent to this sign is an advertisement for Cable Beach Club Resort and Spa endorsed with a, plausibly, colonial East Asian stamp over an eclectic image visualizing outdoor fine dining under white umbrellas, overlooking camels passing between well-watered lawns under palm trees backgrounded by sea. The destination Broome map (2019) suggests that 'Cable Beach', 'Dampier Creek' and 'Broome' are the three most significant areas to visit. The first item of trivia adjacent to the map explains that Australia's top beach was named in 1889 after the telegraph cable that 'runs between Java and 
Broome'. Amongst the brochures and visitors guides, is a small fold-out guide welcoming visitors to Broome as 'Country of the Yawuru people':

Country created by the Bugarrigarra - the Creation force of songlines and stories enriching the lives of Yawuru people whose world has been shaped and influenced as well by the many Asian and European people who were lured to Broome by the lustre and allure of pearling. (Yawuru Country, n.d)

The guide folds out to a page summarizing Aboriginal contributions and perspectives on seven tourist sites in the town. These summaries of place histories gently introduce racial segregation laws of the $20^{\text {th }}$ century including the Aborigines Act 1905 which 'dictated where they lived, where they worked, who they married and where the kids stayed.' The opening and closing summaries provide a cosmopolitan picture of Broome's Chinatown and a camp where many 'Asian and Aboriginal workers lived... building and repairing luggers that lined the foreshore'. Images on the back of the guide suggest that Cable Beach and the Japanese Cemetery are key places to visit when discovering Broome.

Cable Beach is remembered affectionately as a place of leisure and fun for young people in a pristine environment in texts produced (Cochrane, 2012) and published (Bin Demin, 2007) by Broome's substantial indigenous media companies:

Sometimes we would head out to the white stretch of coast known as Cable Beach - it got its name from the communication cable that ran from Broome to Java in Indonesia. We would make a day camp just below the cliff edge that gently fell away down to the beach, and take a big canvas sheet and hang it from long poles for shade. We usually had the whole fourteen miles of pristine, white sand and glistening, turquoise water to ourselves. (Bin Demin, 2007: 23) 
Indigenous references in the main public tourist area of Cable Beach were difficult to identify, and a new master plan for the area has been designed for the Shire of Broome (Close, 2017) partly to address this deficit. The Cable Beach Foreshore Master Plan is aimed at ensuring that Yawuru people and their protocols are applied in protecting the area known to them as Walmanyjun. Yawuru people should be involved in future planning, in construction projects and in developing themes, locations, artworks, interpretation and signage. This participation may enable visitors to the foreshore to encounter indigenous stories of Walmanyjun and the broader region of Minyirr (Close, 2017). Otherwise, visitors can find them described on storyboards at Gantheaume Point seven kilometres away at the southern end of the beach; or they can travel 1.5 kilometres inland to the Nyamba Buru Yawuru office, established on Cable Beach Road after the Western Australian Government accepted a 2006 Federal Court ruling that it recognize the native title rights of Yawuru people (Yawuru Corporate Group, 2013). Meanwhile, the foreshore master plan calls for better access, commercial opportunities and place activation with continuation of key events such as horse polo and the Shinju Matsuri multi-cultural festival. The 47-page masterplan includes a new 'Cable Beach Plaza' and an improved 'Cable Beach Park' but makes no mention of the actual undersea cable that landed on the beach or its associated telegraph network. History of the telegraph network has been reduced to name only in public representation at the Cable Beach foreshore. From time to time, in recent years, this history has been brought to light. One of our informants, Chris Maher, provided a photograph of how he had addressed this history through an art installation for A View to Asia sculpture festival on the foreshore at the 2017 Shinju Matsuri festival. The sign attached to the installation, a large role of contemporary telecommunications cable, suggests that little has changed in the language promoting high-speed networks in Australia since 1889 when the project was approved by the British Secretary of State of the Colonies and endorsed by the Governor of Western Australia, Sir Frederick Napier Broome: "We are building a communication network for the future... to achieve the fastest possible Telegraph 
speeds". Also, local ABC radio journalist Vanessa Mills provided photographs showing another informant, heritage activist Clive Johnson, finding a section of the cable buried beneath a meter of sand on the beach. For more information and cable artefacts, the richest archive is a six-kilometre drive across Minyirr peninsular to the Broome Museum.

The Broome Historical Society and Museum offers glimpses of the rich multicultural histories in the area mostly after the colonial town was proclaimed in 1883. Compared to the authors' experiences of walking through other museums in Western Australia, the contributions of Aboriginal and Asian people to the town are more apparent here in the displayed images, artefacts and texts. They include representations of people defying the White Australia Policy and the Immigration Restriction Act, enacted with the federation of Australia in 1901 when, in Broome, 'there were 1,358 Asians working in the pearling industry and only 132 Europeans'. After using kidnapped Aboriginal labour in the second half of the $19^{\text {th }}$ century, the 'divers, their tender and deck crews were for the most part indentured men from the Dutch East Indies (Koepangers), Southeast Asia, the Philippines, China and Japan,' reads a display. Apparently, it was dangerous work. Two years before the undersea cable was drawn across the sea, more than 140 men drowned when a storm slammed into the pearling fleets.

\footnotetext{
A long narrow corner of a section in the museum is dedicated to the technologies of empire and those resisting or preceding it. On approach, the left side shows horrific chains used to incarcerate Aboriginal peoples as well as rifles including some used in policing the $1920 \mathrm{~s}$ racial conflict between Broome residents of Malay and Japanese heritage. The right side of the room has displays of invention, art and communication technologies: firstly, a collection of pre-colonial artefacts, black-and-white photographs of Aboriginal gatherings, technologies and artistic performances in the region as well as contemporary texts and artefacts, such as carved boab nuts and a stone axe created by Aboriginal artists. Next to this display, we
} 
encounter a half-metre restored section of cable and its description (which uses the Dutch Colonial spelling of Banyuwangi):

laid in 1889 from Banjoewangie, Java coming ashore at Cable Beach linking up to the Cable House - now the Courthouse. This placed the colony in direct communication with the London pearling market and the outside world.

Directly below the cable is a posterboard, titled 'COMMUNICATION', which describes the introduction of electric telegraph to Broome and its associated post office. The poster also describes the the opening of Broome's telephone exchange in 1908, the Coastal Wireless Station in 1913 and the establishment of the Overseas Telecommunication Commission (OTC) in 1946 that nationalized international telecommunications services into and throughout Australia. OTC merged with the domestic service to become the company branded 'Telstra' today. Visitors are told that the 'cable link was the catalyst that turned what was essentially a base camp for pearlers into a town'. The displays of artefacts roughly follow this line of development from cable signal amplifiers to telegraph sounders and Morse jiggers, to typewriters and telephone handsets, to a telegraph-exchange switchboard and 500-watt transmitter operated by OTC. A poster on the transmitter describes Broome's long association with the telecommunications industry:

dating back to the arrival of the British Empire telegraph network extension cable from Banjuwangi. With the arrival of that telecommunications cable, Broome became, in 1889, Australia's gateway to the world.

Passing the weapon and communication displays, we approach a flat screen playing the hello girls video documentary that voices women's stories of working in Broome's telephone exchange. If not for this prominent screening of the hello girls, visitors may not notice the diversity of skilled workers in the history of telecommunications. For example, Google 
searches for 'Broome Banyuwangi cable' from Perth in 2020 highly ranked the Engineers Australia (2006) nomination for installing memorial plaques in Broome. The nomination provides detailed biographies of five British men - a lord and four knights - of wealth and status who led or endorsed the project. It also provides a short biography on an inventive electrical engineer involved in the project, the names of a captain and his cable-laying ship, the name of a superintendent and the name of the first person to send a cable from Perth to London. Everyone else involved was lost or reduced, for example, to the 'staff, tradesmen and Chinese "coolies" who built and equipped the Cable House and Cable Station. Whereas in the hello girls video, women staffing the telephone-exchange are named, have voices and consider themselves 'to be the important people in town'. These 'front line people... were coloured girls, they were Broome girls,' says Doris Mathews, regarding her co-workers of Aboriginal, Asian and European heritage. The video shows that in the telephone exchange and their social networks in Broome, these women countered the structure of racism and misogyny being reproduced in Australia in the decades after World War 2. Unfortunately, the names and accounts of non-white people working for the earlier telegraph service have been lost from contemporary public representation in Broome.

A photograph on the COMMUNICATION poster in the museum shows seven men standing behind four people seated at tea, the caption reads: 'Bishop Trower and the Fountain family with their servants at Cable House in 1913.' The same photograph is captioned with only British names in Sickert's (2017) book which aims to provide a more diverse social history of Broome settlement's early years: 'The names of the rest of the men - staff and servants were not recorded' (39). When the same photograph appears in Goolarri Media's documentary on the history of Broome's Courthouse to show how the building was used initially as a cable station, the voice of renovator Marcus Duncan is heard: 
They were like high British society and they had their Indian servants and quarters, and they had a tennis court up the back. It was like a grand house to live in. (Goolarri Media Enterprises \& Broome Historical Society, 2006).

This notion of the elegant building and grand British presence being introduced to Broome with the undersea cable operations occurs consistently in coffee-table history books (Norman \& Norman, 2017; Sickert, 2017), posters and plaques about the cable station, no matter how socially progressive or regressive these texts may appear to be. The poster locked behind glass on the outside of the courthouse offers an official position on the history:

This building, one of the first pre-fabricated buildings in Australia's North West, was constructed in $1889 \ldots$ The ironwork was designed and manufactured in Britain and the interior teak was imported from Singapore. The British staff who occupied the building (known as "Cable House") were part of a network of people who transmitted messages through the world. A submarine telegraph cable connected Broome to Java, and a telegraph line ran overland to Perth.

In the courthouse gardens, which regularly host an open market (Broome Courthouse Markets, n.d.), the Historic Engineering Marker, installed in 2006, describes the 1,650-kmlong submarine cable from 'Banjoewangie' to Broome as increasing the security of Australia's overseas communications by being the 'third link to Europe'; and names three British engineers supervising the cable laying in 10 days using the SS Seine. Public history of the undersea cable in Broome recalls the names of British supervisors, a boat and Javanese places, while backgrounding and not naming the diverse workforce involved in the project. Meanwhile, history scholars have begun to identify some of the staff and servants left out of the Cable Station picture; such as Marjoeki, a Javanese man who worked in Broome for decades (Martinez, 2017, 239-241). Marjoeki stands proudly, looking to Camera, third from 
left among the people behind the station manager's family in the 1913 photograph. Yet, he is so publicly unknowable in the texts, with this photograph, that account for telegraph operations in Broome.

\section{Seeking the memory hub: Banyuwangi and Asrama Inggrisan}

Unlike Broome, Banyuwangi has few resources containing documentation on the $19^{\text {th }}$ century telegraph connection to Australia. There was also minimal documentation about Asrama Inggrisan (British Hostel) as the prominent building that could link the town's story to Australia. Interestingly, the limited written resources on Asrama Inggrisan do not reflect the attention paid to it by the Banyuwangi government. In recent years, the local government has recognized substantial potential in the complex as cultural heritage and as an economic resource. The Banyuwangi regent (Bupati) has signed Bupati Decree Number 188 Year 2018 to formally recognise Asrama Inggrisan as cultural heritage (JDIH, 2018).

Wibowo (personal communication, 2019) said a team from Banyuwangi Tourism Board had begun, in 2019, studying Asrama Inggrisan for the purpose of revitalisation. Wibowo says: 'the building will be revitalised by the government and utilised as a museum and hotel in 2020'. The building, at 5 Diponegoro Street, is located in the heart of Banyuwangi city next to the Blambangan park. The park was known during the Dutch era as Tegal Loji, the recreation area for colonists. The word 'loji' is based on the English word 'lodge', associated with Asrama Inggrisan that was used to lodge Dutch businessmen (Wibowo, personal communication, 2019). The complex is just a kilometre from the well-known Boom beach. Boom beach was used by the Dutch colonial government as a port for natural commodities such as nutmeg and clove. Today, Boom beach is managed as a yacht seaport by state-owned company PT Pelindo III. In this context, Regent Anas aims to showcase the historic and strategic position of Asrama Inggrisan through property development for heritage tourism 
(Anas, 2019). The plan includes acclaimed Jakarta-based architect, Yori Antar, designing a new version of Asrama Inggrisan for use as a cultural centre and economic resource (Anas, 2019: 228 - 229).

Currently, Asrama Inggrisan is owned and managed by the Indonesian military body known as KODIM 0825 Banyuwangi. During World War II, Japanese colonial authorities used Asrama Inggrisan as an army base (Munawir, personal communication, 2020). Asrama Inggrisan contains two storey buildings of, locally, unique architecture with teakwood structures and 3-ply-brick walls to resist the local climate. The complex contains rooms and toilets; and is surrounded by a fortress. Today, the fortress functions as a military sanctuary, especially for low-ranking soldiers. Hawker carts owned by soldier families are stored in the fortress's parking area. Its rooms are inhabited by Indonesian soldiers and their families. Several rooms, used as prison cells during the Dutch era, have become soldiers' homes. Prison bars are covered with plywood and plastic flowers. In the complex foreground, there is an underground tunnel below a thick iron manhole cover inscribed with its British manufacturer's title, 'Burn Brothers Rotunda Works 3 Blackfriars Road London S.E.'. The tunnel is believed to house the cable that was laid from the complex to Santen island (around two kilometres from Asrama Inggrisan) and extended to Australia (Wibowo, personal communication, 2019). The fortress also contains a societeit (ballroom) building, a post office and an old church. The post office is believed to have housed the telegraph operations.

Limited public information about Asrama Inggrisan and the telegraph station in Banyuwangi have motivated local people to perform independent investigations. Several groups are interested in Banyuwangi history, such as KOSEBA - Komunitas Sejarah Banyuwangi (Banyuwangi History Community) - and BTD - Banjoewangi Tempo Doeloe (Olden Days of Banyuwangi). Yet, documentation of the Banyuwangi telegraph station is scattered and hard 
to find. Munawir, the founder of BTD, says his group investigates by collecting old books, magazines, newspapers, documents and notes from society (personal communication, 2020). He says, 'we collect documents on Banyuwangi history, buy them with our own funding, and digitally scan the documents with our own resources and place them in our community library' (personal communication, 2020). BTD members are active on social media like Facebook. With 25 thousand group members on Facebook, posts on the BTD page (Banjoewangi Tempo Doeloe, 2020) generates discussions and debates about the history of Banyuwangi, including the existence of a telegraph station and Asrama Inggrisan.

If Facebook is utilised as the discussion forum for Banyuwangi history enthusiasts, then Youtube is used for an urban perspective of visualising Asrama Inggrisan. Content creators visit Asrama Inggrisan and perform their investigations based on what they know about the place and its history. Scientific approaches are used in videos incorporating interviews, other data and statistics. For example, a video by Rossalita (2019) provides a narrative and basic information about the building complex. Their video has been viewed several hundred times. Other creators adopt different approaches, drawing on urban legends in their videos. The IDN Times (2019) account received 32 thousand views for a video of Asrama Inggrisan horror stories, indicating the effectiveness of mythical and supernatural approaches in storytelling around Asrama Inggrisan. The popularity of this urban legend style of visualizing Asrama Inggrisan suggests that people may be aware of its role in the early days of telecommunications but are more engaged by the supernatural myths surrounding the complex.

Banyuwangi people's memories were limited substantially to the locality relating to ghost stories or old photos taken during the colonial era. There was no indication of any social imaginaries taking them across the border and thinking about the other side of the cable 
connection: Broome or Australia. Also, the limited amount of public information and documentation available on the cable network in Banyuwangi reflected a lack of contemporary local media coverage of the historic cable network.

Yet, variety in available information on Asrama Inggrisan and the telegraph connection has made different impressions on Banyuwangi society. BTD founder Munawir says he knows of Asrama Inggrisan as Dutch colonial heritage, known as 'Rumah Pajang' (Long House) during the Dutch colonial period: 'I read from the documents that I collected, that Asrama Inggrisan was exclusively used as the elite space for the Dutch' (personal communication, 2020). Munawir confesses that he did not know how it was then called Asrama Inggrisan. He thinks the name probably came from Banyuwangi people who have more respect for the British. Even though, Munawir continues, 'I understand that the Dutch in the 1870 s gave permission to the British-China joint-company to manage the building' (personal communication, 2020). Unfortunately, according to Munawir, information about Asrama Inggrisan as the telegraph office relaying cables to Australia has been rarely discussed. He says, 'Banyuwangi people just simply correlated the building with British colonialism, but gained no idea about the Australian piece on the story' (personal communication, 2020).

History enthusiasts, such as the BTD group, are interested in the story of old Banyuwangi, including the history of the monarch that controlled the area before the colonial era. Banyuwangi was popularly known as Blambangan land, a kingdom dominating the southeast hook of Java from the $16^{\text {th }}$ to $18^{\text {th }}$ centuries before being devastated by Dutch-led forces by the early 1800s (Margana, 2007). The Blambangan Kingdom's buildings and other heritage were almost totally destroyed by the invading colonial forces. 'We do not have any historyrelated building that correlates with Blambangan in Banyuwangi,' says Munawir (personal communication, 2020). 
Since the Blambangan heritage had been destroyed, Banyuwangi society - including the BTD community - have placed their interest in colonial heritage (Munawir, personal communication, 2020). Even though the colonial era connotes land invasion, slavery and inhumane treatment by the Dutch, according to Munawir, Banyuwangi society supports the preservation of old Dutch buildings. 'These buildings are our only legacy from the past,' Munawir claims (personal communication, 2020). He says the Banyuwangi government is unaware or ignorant of the history of the built environment (personal communication, 2020). He added:

We want the government to preserve them. But we are disappointed and consider them being ignorant by destroying Dutch era buildings and building a new commercial area above it. Many buildings belong to individual possession and are treated and sold as they like. (personal communication, 2020).

Munawir's memory on Asrama Inggrisan, the colonial heritage, and the telegraph cable connection to Australia has contributed to the social memory articulated by the BTD community. Munawir explains that the telegraph station has never been an integral part of Banyuwangi society. Despite its location in the city centre, few people understand its history. The telegraph operating business is colonial business. Banyuwangi locals only remember the Asrama Inggrisan complex as an elite area of the Dutch colonial era. The place was untouchable to locals. In recent years, the society has begun responding to history by providing their own versions of the place and its history through social media. As noted by Castoriadis (1987: 145), 'no society can exist that does not organise the production of its material life and its reproduction as a society'. Banyuwangi people perform their own searches for values as a society. Munawir and his community have collected what they can to make sense of the old buildings in Banyuwangi, including Asrama Inggrisan. On the other 
hand, local government considers the heritage buildings as important economic assets that should be exploited effectively. The intrinsic values of cultural heritage seem less important to local government because many old buildings near the site have been destroyed this century without community consultation. This dual approach to valuing heritage buildings may impact on how people in Banyuwangi remember and manufacture their identities in coming days and in the distant future.

Like other coastal regencies in Java, Banyuwangi's development has been heavily influenced by divisive dynamics around ethnic, religious and cultural diversity (Margana, 2015).

Collapse of the Blambangan state and the destruction of its seat of power by Dutch forces in the late 18th century amid a protracted clash between Hindu and Islamic civilizations in Java has supported an enduring stigmatization of Blambangese (Osing) people by outsiders in historical treaties, stories, arts and performances. This divisiveness and stigmatization have made it easier for them to forget particularities of Banyuwangi's heritage, and some attempts at memorialization there have been met by violence (Margana, 2015). The contemporary social imaginary's lack of reference to Banyuwangi as a node in the first world-wide telecommunications system can also be understood through Kusno's (2000) observation that the Indonesian postcolonial nation has, largely, been represented in modernist architecture that ignores the colonial past: while colonists tend to excavate past architecture, nationalists represent indigenous power by building new things. Recognizing these tensions enables an appreciation of the complexities around the Banyuwangi government's plan to redevelop Asrama Inggrisan as a hotel and cultural centre for future tourism.

\section{Connecting the cable station communities}

Social imaginaries of the old telegraph network differ substantially between Banyuwangi and Broome, despite the network's cable station buildings and grounds sharing the broadly similar 
fates. Both stations were taken over for military purpose in wartime: Broome in World War I, and Banyuwangi in World War II. Subsequently, the buildings have been used for the internal policing of their surrounding communities: Courthouse in Broome, and Military District Command in Banyuwangi. Local communities used the space of their grounds for temporary market commerce: outdoor markets in Broome, and hawker cart parking in Banyuwangi. Despite some functional similarities, social imaginaries of the undersea cable network differ radically between the towns. In Broome, the telegraph station is memorialized for introducing an era of colonial sophistication that turned a pearling outpost into a town. This cultural logic enables Java and Banyuwangi to be named and celebrated publicly in Broome for facilitating colonial era communication between Britain and Australia. In Banyuwangi, Dutch colonial time and space - within which the telegraph system operated - represents destruction of the Blambangan Kingdom and enslavement of its people. Within a cultural logic that sees colonization as bad and racially divisive, memories of the undersea cable connection to Australia have not been sustained. In Broome, the undersea cable seems to be remembered unproblematically in association with the names of British lords, knights and engineering supervisors as well as nameless workers from Asia. Australia's continuing celebration of the colonial period and Indonesia's distaste for it helps us to understand why $19^{\text {th }}$ century telegraph cables are dug up and displayed in Broome but remain buried and forgotten in Banyuwangi.

There is an ocean-size gulf between the dominant social imaginaries of the undersea cable network in the two towns, yet there are also similarities between some sectors of their communities. Government officials, heritage volunteers and entrepreneurs in both towns have come to recognize value and tourism potential in places associated with the $19^{\text {th }}$ century cable network. Also, Indigenous heritage leaders in both towns recognize the harm of colonial technologies and practices but also support the collecting of archives on the cable-network 
period to further understandings of what happened to their own people. Collecting and storing archives on colonial era technologies falls to dedicated volunteers in both towns, while government attention focusses on master planning tourist experiences of Cable Beach in Broome and the commercial heritage redevelopment of Asrama Ingrissan in Banyuwangi.

Fieldwork on the cable network drew attention in both towns. In Broome, $A B C$ radio requested an interview and we were invited to contribute to a future multicultural arts festival on Cable Beach. In Banyuwangi, news of our research on the Banyuwangi-Broome connection appeared in local and national print and online media within a day of our meeting with the Regent. The news portrays the fieldwork as a breakthrough in the connection of Indonesia and Australia (Winarno, 2019). Furthermore, the news could be used as a medium for Banyuwangi society to imagine possibilities of connection with counterparts in Broome. Yet, the news mostly circulated within national languages and within local audiences. To reconnect the communities of Broome and Banyuwangi in a meaningful and ethical way would require a more artful form of electronic communication that is aware of background structures and engages with local ways of thinking as well as provisional possibilities (Rizvi, 2017). Recommendations for further research include engaging Indigenous artists in constructing the communication links they would like to see between communities in the two towns. Such research may challenge master narratives (Star, 1999) at the cable landing sites while surfacing invisible work and insights about diverse participation in the development and operation of global electronic communications networks.

Acknowledgements

This research was supported by a Small Grant awarded by the School of Media, Creative Arts

and Social Inquiry at Curtin University and a Visiting Fellowship awarded by the Communications Department, Faculty of Political Sciences at Universitas Airlangga. 


\section{References}

Allmark P and Wahyudi I (2019) Travel, sexuality and female Indonesian domestic migrant workers in Hong Kong. Continuum Journal of Media and Cultural Studies 33(5): $630-642$.

Anas AA (2019) Anti-Mainstream Marketing: 20 Ways Changing Banyuwangi. Jakarta: Gramedia

Banjoewangi Tempo Doeloe (2020) Facebook. Available at: https://www.facebook.com/groups/471315029707535 (accessed 21 July 2020).

Bin Demin S (2007) Once in Broome. Broome: Magabala Books.

Broome Courthouse Markets (n.d.) About Us. Available at: https://www.broomemarkets.com.au/about-us/ (accessed 10 June 2020).

Castoriadis C (1987) The Imaginary Institution of Society. Cambridge: Polity Press.

Close A (2017) Cable Beach Foreshore Master Plan Final Report, The Shire of Broome, September.

Cochrane M (2012) the hello girls, DVD, Goolarri Media Enterprises.

Destination Broome (2019) destination broome map, August November.

Engineers Australia (2006) Nomination for historic engineering marker plaques and ceremony report, May. Available at: https://portal.engineersaustralia.org.au/system/files/engineering-heritageaustralia/nomination-title/Broome_Java_Nomination_Ceremony_Report.pdf (accessed 6 September 2019).

Goolarri Media Enterprises \& Broome Historical Society (2006) Old Broome, Broome Historical Society.

Headrick DR and Griset, P (2001) Submarine telegraph cables: Business and politics, 18381939. Business History Review 75(3): 543-578. 
IDN Times (2019) PM:AM Ketakutan Bang Doel Saat Berada di Rumah Inggrisan Banyuwangi. Available at: https://www.youtube.com/watch?v=8ZhyR1_VBKE (accessed 21 July 2020)

JDIH (2018) Bupati Banyuwangi Decree Number 188/372/KEP/429.011/2018 on the Establishment of Rumah Inggrisan as the Cultural Heritage Building (in Indonesian language). Available at http://jdih.banyuwangikab.go.id/dokumen/keputusan_bupati/SK_NO_372_TAHUN_2 018_CAGAR_BUDAYA_INGGRISAN.pdf (accessed 21 July 2020).

Kerr T (2012) Reproducing temples in Fremantle. International Journal of Heritage Studies 18(1): $1-17$.

Kusno A (2000) Behind the Postcolonial: Architecture, Urban Space and Political Cultures in Indonesia. London: Routledge.

Owen C (2016) 'Every Mother's Son is Guilty': Policing the Kimberley Frontier of Western Australia 1882-1905. Crawley: UWA Publishing.

Margana S (2007) Java's last frontier: the struggle for hegemony of Balambangan, c. 1763 1813. Doctoral Dissertation. Leiden University repository. Available at: https://openaccess.leidenuniv.nl/handle/1887/12547 (accessed 20 July 2020).

Margana S (2015) Outsiders and stigma: Reconstruction of local identity in Banyuwangi. In:

Legêne S, Purwanto B and Nordholt H (eds), Sites, Bodies and Stories: Imagining Indonesian History. NUS Press, pp. 210-231.47

Martínez J (2017) Asian Servants for the Imperial Telegraph: Imagining North Australia as an Indian Ocean Colony before 1914. Australian Historical Studies 48(2): 227-243.

Munawir (2020) personal communication. 27 June 2020

Norman GV \& Norman, JEdeB (2017) Broome 1910. Strathfield: Norman and Norman. Nyamba Buru Yawuru (n.d.) Yawuru Country: Broome WA. 
Rizvi M (2017) The moral ecology of colonial infrastructure and the vicissitudes of land rights in rural Pakistan. History and Anthropology 28(3): 308-325.

Rossalita T (2019) Asrama Inggrisan Banyuwangi. Available at: https://www.youtube.com/watch?v=bvEo6I5ulsA (accessed 21 July 2020).

Sickert S (2017) Beyyond the Lattice: Broome's Early Years. Broome: Backroom Press.

Star SL (1999) The ethnography of infrastructure. American Behavioral Scientist 43(3): $377-$ 391.

Steele M (2017) Social imaginaries and the theory of the normative utterance. Philosophy \& Social Criticism 43(10): 1045-1071.

Thomas PN (2019) Empire and Post-Empire Telecommunications in India: A History. New Delhi: Oxford University Press.

Vocus Communications (2018) Vocus' infrastructure helps secure Australia's digital future. Available at: https://www.australiasingaporecable.com/articles/vocus-infrastructurehelps-secure-australias-digital-future/ (accessed 30 March 2020).

Von Schnitzler A (2013) Traveling technologies: Infrastructure, ethical regimes, and the materiality of politics in South Africa. Cultural Anthropology 28(4): 670-693.

Wibowo BA (2019). Personal communication. 08 December 2020.

Winarno HH (2019). Curtin University-Unair telusuri jejak sejarah Inggrisan Banyuwangi. Merdeka, 9 December. Available at: https://m.merdeka.com/peristiwa/curtinuniversity-unair-telusuri-jejak-sejarah-inggrisan-banyuwangi.html (accessed 21 July 2020).

Yang DY (2010) Technology of Empire: Telecommunications and Japanese Expansion in Asia, 1883-1945. Cambridge, MA, \& London: Harvard University Press. Yawuru Corporate Group (2013) Yawuru Native Title Determination, February. 